Available online on 15.06.2020 at http://ajprd.com
(C) 2013-20, publisher and licensee AJPRD, This is an Open Access article which permits unrestricted non-
commercial use, provided the original work is properly cited

Open $\mathcal{O}_{\text {Access }}$

Review Article

\title{
A Review on 2019-nCoV (SARS-CoV-2) in India
}

\section{Pawan Kumar Mahawar, Abhay Sharma}

Kota College of Pharmacy, Kota-Rajasthan, India

\section{A B S T R A C T}

Background: The outbreak of the novel coronavirus, COVID-19, has been declared a pandemic by the WHO on March $11^{\text {th }}$ of 2020. Novel Coronavirus infection mediated pandemic started in China in December 2019 and is still killing 1000 s of people throughout the world. The second most populous country, India too is fighting against this infectious disease. The country is taking effective measures to curb the pandemic by exerting extensive campaigning on sanitation and strict social distancing measures to quell the explosion of the infection rate.

Treatment: No drugs are currently approved for Coronavirus Disease-2019 (COVID-19), although some have been tried. In view of recent studies and discussion on tested drugs on COVID-19 patients of India, I aimed to review existing literature and relevant websites regarding these drugs used in India including allopathic, plasma therapy, Ayurvedic and homeopathic medication.

Key words: Coronaviridae, Nidovirale, management of stroke, situated patients, allopathic treatment.

A R T I C L E I N F 0: Received 08 April 2020; Review Completed 30 May 2020; Accepted 06- June 2020; Available online 15 June. 2020

Cite this article as:

Mahawar P K, Sharma A, A Review on 2019-nCoV (SARS-CoV-2) in India, Asian Journal of Pharmaceutical Research and Development. 2020; 8(3):135-141. DOI: http://dx.doi.org/10.22270/ajprd.v8i3.744

*Address for Correspondence:

Pawan Kumar Mahawar, Kota College of Pharmacy, Kota-Rajasthan, India

\section{INTRODUCTION}

$\mathrm{N}$ ovel coronavirus (2019-nCoV), officially known as severe acute respiratory syndrome coronavirus 2 (SARS-CoV-2), the etiological agent of the (Corona Virus Disease 2019) COVID-19, emerged in Wuhan, Hubei province, China. On 11th March 2020, The World Health Organization (WHO) declared this disease as pandemic ${ }^{1}$.Coronaviruses (CoVs) are enveloped nonsegmented positive-sense RNA viruses, belonging to the family Coronaviridaeand the order Nidovirales, and are broadly distributed in humans and other mammals ${ }^{2}$. $\mathrm{CoVs}_{\mathrm{s}}$ is four types as follow

- Alphacoronavirus

- Deltacoronavirus

- Beta coronavirus

- Gamma coronavirus
ICTV (International Committee on Taxonomy of Viruses) announced "severe acute respiratory syndrome coronavirus 2 (SARS-CoV-2)" as the new name of the 2019 novel corona virus on 11 February 2020. This name was chosen because the virus is genetically related to the coronavirus responsible for the SARS outbreak of 2003. While related, the two viruses are different. WHO announced "COVID19 " as the name of this new disease on 11 February 2020 caused by SARS-CoV-2.

The symptoms resulting from SARS-CoV-2 or the 2019$\mathrm{nCoV}$ infection at the prodromal phase include fever, dry cough, and malaise specifically. The basic symptoms of COVID-19 as portrayed in Figure 2. 


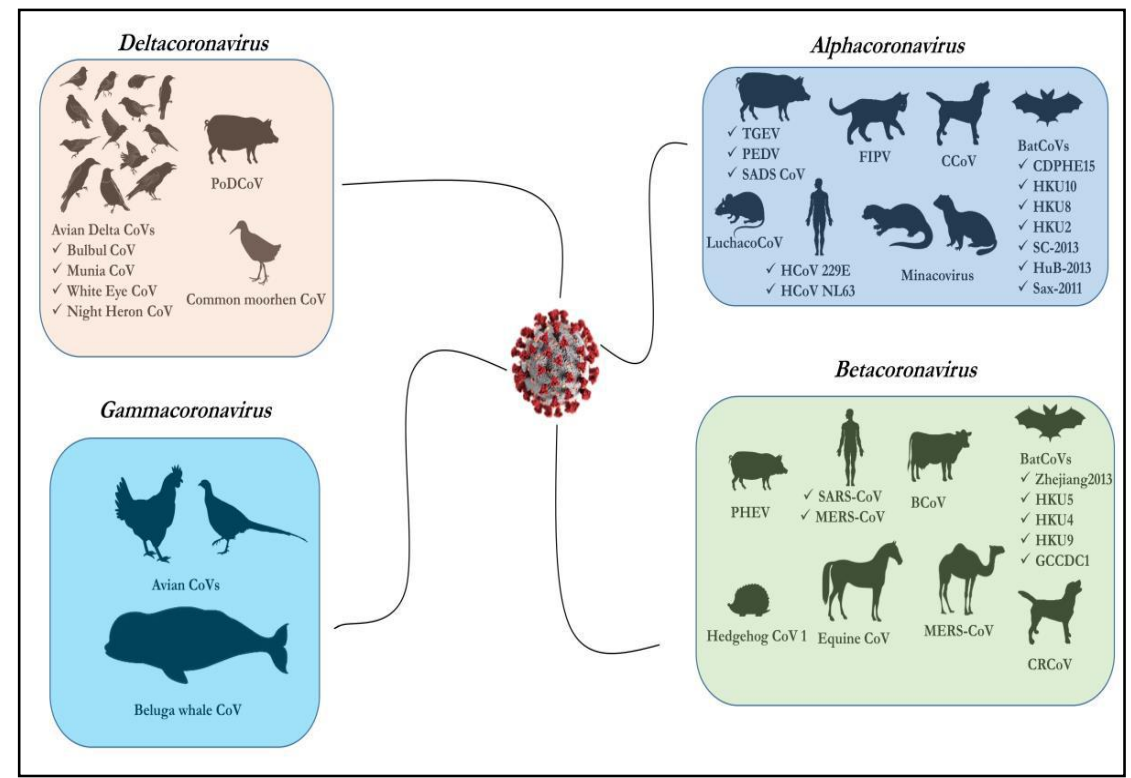

Figure 1: Depiction of different coronaviruses under four Genus (Alpha, Beta, Gamma and Deltacoronavirus) found in a diverse group of Mammalian and avian species ${ }^{3}$

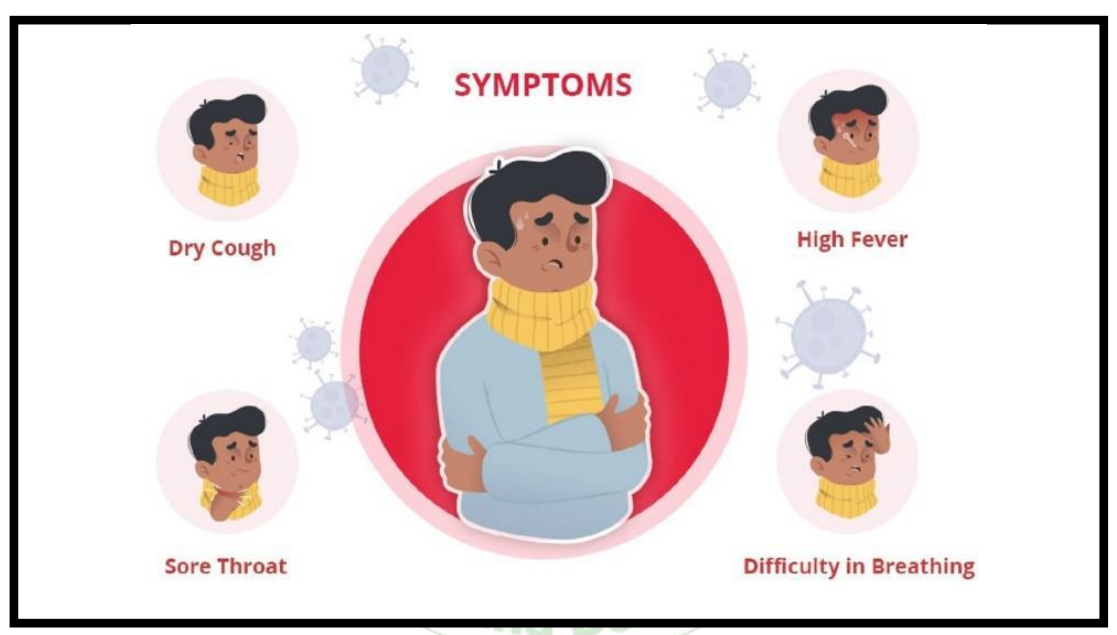

Figure 2: Schematic of COVID-19 symptoms ${ }^{5}$

The most essential factors in preventing the spread of the virus through these means are to empower the citizens with the right information regarding the disease, teaching them the appropriate cough and sneeze etiquette and taking precautions as per the advisories. It is also imperative that financial and majorly psychological support is provided to the citizens.
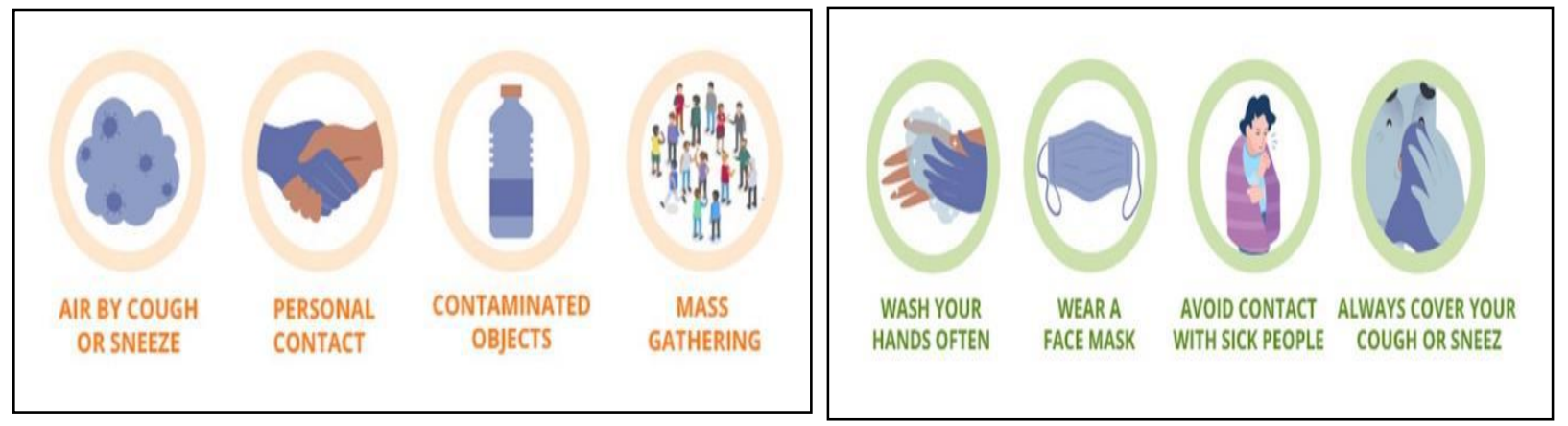

Figure 3: Schematics of how 2019-nCoV is spread and preventive measures of COVID-19

In India, the first laboratory-confirmed case of COVID-19 was reported from Kerala on January 30, 2020. Subsequently, two more caseswere reported from Kerala. All cases had recentlyreturned from Wuhan, PR China, had mild illnessand were managed symptomatically. More such casescan be expected amongst individuals travelling
fromChina, and Wuhan in particular, and amongst their close contacts ${ }^{6}$.The first case was three persons travelled from Wuhan, China to Kerala, India which is now considered as the epicenter of the pandemic. Later throughout India, the people who met travelers from infected countries contracted with the disease. First 
COVID-19 death in the country was reported on March 13th, 2020. Although being a country of 1.2 billion and a neighbor of China, India has fairly contained the spread of COVID-19 infection to date ${ }^{7}$.Several thousand individuals are on surveillance in India due to reasons of fever, recent travel to China and concordant entries in the relevant surveillance questionnaires. ${ }^{8}$

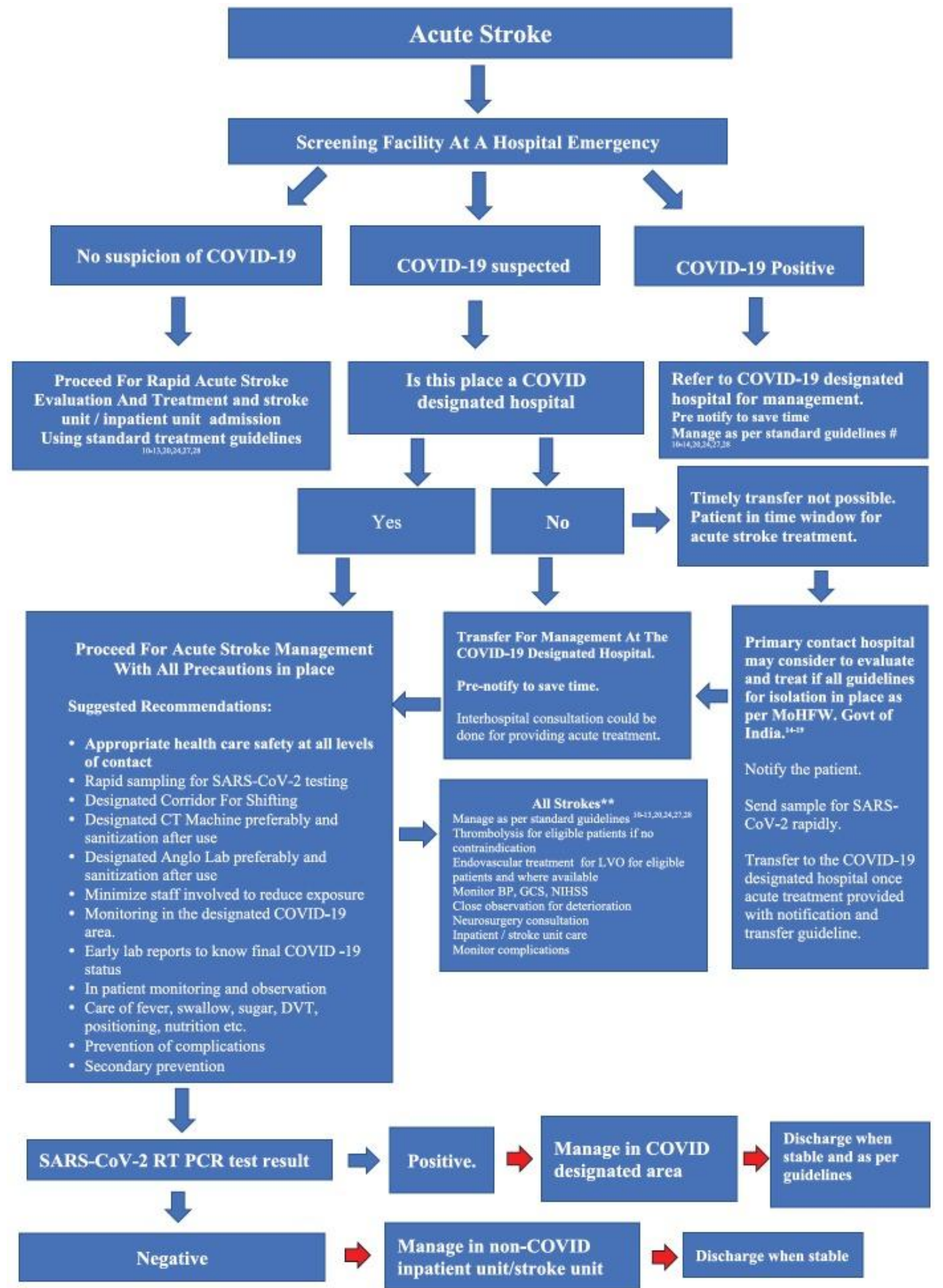

Figure 4: Suggested pathway in the management of stroke during the COVID-19 pandemic. COVID-19: Corona virus associated disease 2019, ** Ischemic stroke, intracerebral hemorrhage and cerebral venous thrombosis commonly, \# In seriously ill COVID-19 patients treatment decision may be individualised, GCS: Glasgow coma scale, NIHSS: National institute of health stroke scale, BP: Blood pressure, DVT: Deep vein thrombosis, MoHFW: Ministry of Health and Family Welfare, Govt of India. SARS-CoV-2: Severe acute respiratory distress, corona virus $2^{9}$. 
Table: 1 Situated Patients In India ${ }^{10}$

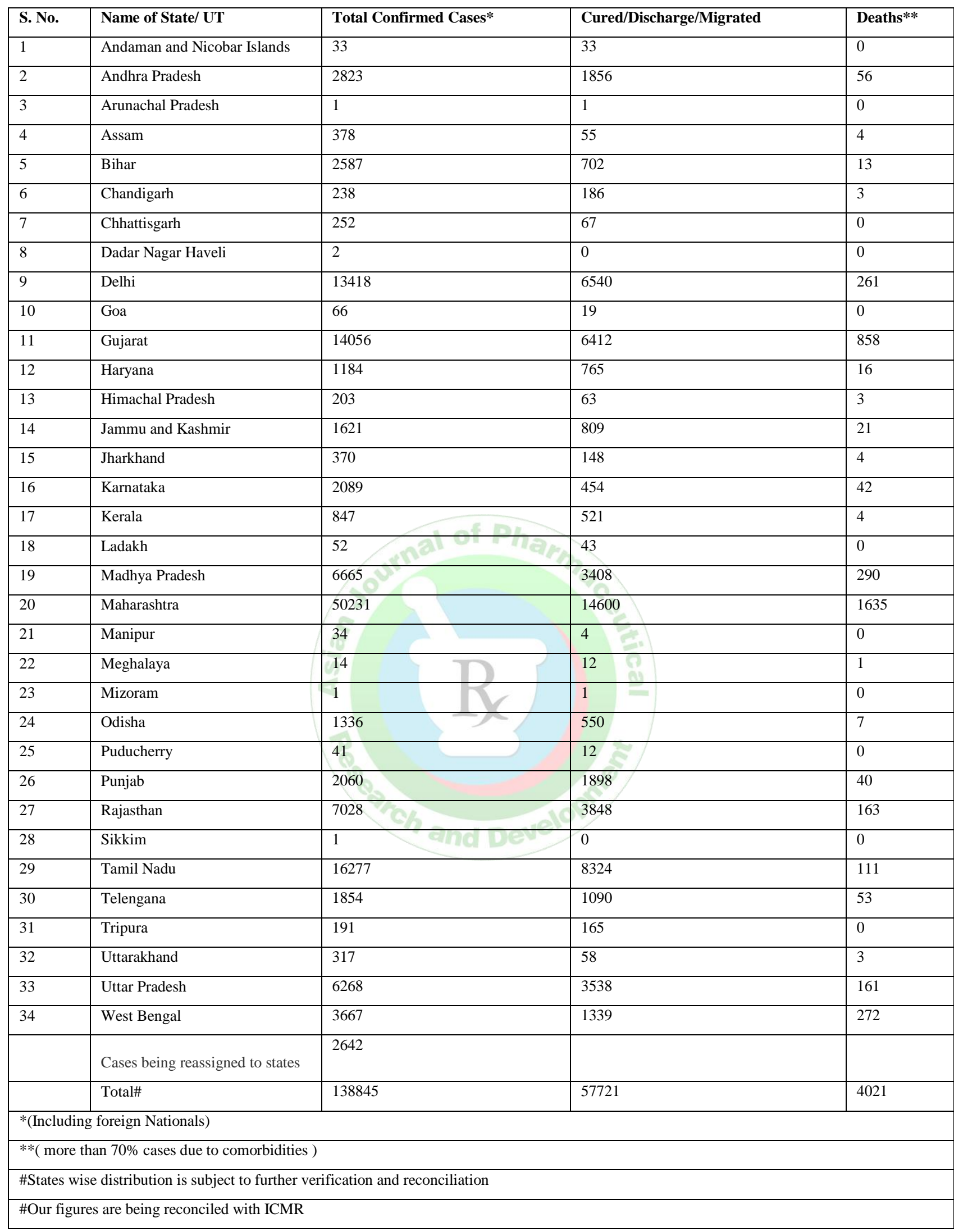

\section{TREATMENT OF COVID-19 IN INDIA}

1. Allopathic treatment:

1) Lopinavir/ritonavir combination therapy: ${ }^{11}$
No antiviral treatment for SARS-CoV-2 infection has been proven to be effective. A few historical control studies or case reports indicate the effectiveness of combination of lopinavir/ritonavir against SARS-CoV and MERS-CoV infections. Ritonavir-boosted lopinavir was approved for 
use amongst HIV-infected individuals in September 2000 by the U.S. Food and Drugs Administration. Lopinavir is always used with ritonavir to reduce the dose of lopinavir and increase the plasma levels of lopinavir as ritonavir inhibits CYP3A isoenzyme. Lopinavir and ritonavir are antiretroviral protease inhibitors used in combination as a second-line drug for the treatment of HIV-1 infection in children and adults and have limited side effects. As per the NACO (National AIDS Control Organization) guidelines, lopinavir/ritonavir is used as a second-line drug in the treatment of HIV in combination with nucleoside reverse transcriptase inhibitors (NRTIs).

\section{Dosage of lopinavir/ritonavir:}

1. Lopinavir/ritonavir $200 \mathrm{mg} / 50 \mathrm{mg}$ - two tablets every $12 \mathrm{~h}$ for 14 days or for seven days after becoming asymptomatic, whichever is earlier.

2. For patients who are unable to take medications by mouth, $400 \mathrm{mg}$ lopinavir $/ 100 \mathrm{mg}$.

3. ritonavir $5 \mathrm{ml}$ suspension every $12 \mathrm{~h}$ for 14 days or seven days after becoming asymptomatic whichever is earlier, via a nasogastric tube.

2) Chloroquine and Hydroxychloroquine (HCQ):

Experimental studies have also demonstrated that chloroquine has potent anti-SARS-CoV-1 effects in vitro, primarily attributable to a deficit in the glycosylation receptors at the virus cell surface, so that it cannot bind to the angiotensin-converting enzyme 2 (ACE2) expressed in lung, heart, kidney and intestine. Since SARS-CoV-2 utilizes the similar surface receptor ACE2, it is believed that chloroquine can also interfere with ACE2 receptor glycosylation thus prevents SARS-CoV-2 attachment to the target cells ${ }^{12-15}$. Chinese researchers who studied the effect of chloroquine in vitro (using Vero E6 cell line infected by SARS-CoV-2) found chloroquine to be highly effective in reducing viral replication that can be easily achievable with standard dosing due to its favorable penetration in tissues including the lung ${ }^{12,16}$.
Since the structure and mechanism of action of chloroquine and hydroxychloroquine (HCQ) are exactly same except an additional hydroxy moiety in one terminal in HCQ, both act as a weak base that can change the $\mathrm{pH}$ of acidic intracellular organelles including endosomes/lysosomes, essential for the membrane fusion. It is believed that both the agents could be effective tools against SARSCoV-1 and SARS-CoV-2. ${ }^{16,17}$

However, an important question that still remains is whether HCQ has a similar effect on SARS-CoV-2 infection. Some data show HCQ effectively inhibited both the entry, transport and the post-entry stages of SARS$\mathrm{CoV}-2$, similar to the chloroquine and one study found HCQ to be a more potent agent than chloroquine in inhibiting SARS-CoV-2 in vitro ${ }^{18,19}$

\section{Dosage of chloroquine/hydroxychloroquine:}

i. Chloroquine $500 \mathrm{mg}$ orally per day.

ii. Hydroxychloroquine $400 \mathrm{mg}$ orally per day for 7 to 10 days.

\section{Plasma Therapy:}

Encouraging observational reports in small numbers of patients have aroused wide-spread interest in the use of convalescent plasma for severely ill COVID-19 patients on ventilators. Randomized controlled clinical trials have commenced with this treatment approach. In general, in viral illnesses antibody response is much brisker in those who have a clinical illness than in those with asymptomatic or subclinical illness. Patients with clinically diagnosed COVID-19 syndrome may be the ones with the highest titers of antibodies. Utilizing the syndromic approach may help identify potential plasma donors in resource poor settings. Since those with the clinical syndrome will be the larger number than those with PCR-proven SARS-CoV-2 infection, a physician can select willing individuals who have recovered from the clinical syndrome for checking on antibody titers prior to plasma pheresis and, thus, reduce costs. $^{20}$

\section{Ayurvedic treatment: ${ }^{21}$}

Table 1:Ayurvedic preventive measures including the government declared options for apparently healthy individual with no sign and symptom of COVID-19( $n=110)$.

\begin{tabular}{|l|l|l|}
\hline Ayurveda medicaments & Dose & $\begin{array}{l}\text { No. of practitioners with positive } \\
\text { response }\end{array}$ \\
\hline $\begin{array}{l}\text { Decoction of Sunthi, Lavang, Pippali, } \\
\text { Maricha, cinnamon bark, tej patra }\end{array}$ & $\begin{array}{l}2 \text { gm each in 200mlwater reduced to 50ml-50 } \\
\mathrm{ml} \text { twice empty stomach }\end{array}$ & 75 \\
\hline $\begin{array}{l}\text { Haridra milk or Cow ghee (Emulsified fat)-10 } \\
\text { ml with rice/roti }\end{array}$ & $\begin{array}{l}5 \text { gm Haridra boiled in250 ml of milk and } \\
\text { reduced to } 200 \mathrm{ml}\end{array}$ & 110 \\
\hline Hyawanprash Avaleha & $10 \mathrm{gm}$ once before break fast & 110 \\
\hline Aswagadha tablet -250mg & 2 tab twice after food & 59 \\
\hline Amalaki Churna & 10 gm at night along with Luke warm water & 57 \\
\hline $\begin{array}{l}\text { Dhopana of house by Resin of saal } \\
\text { Sarjjarasa), Neem leaves, coconut shell } \\
\text { andhingu }\end{array}$ & Morning and evening Fumigation & 110 \\
\hline Smoke allergic patients should avoid & \multicolumn{2}{|l}{} \\
\hline
\end{tabular}


Table: 2:Ayurvedic preventive measures for High risk group/geriatric person/those have history of immigration to other country/who declared self-isolation or quarantine/ pre-symtometic phase of COVID-19 $(n=110)$.

\begin{tabular}{|l|l|l|}
\hline Ayurveda medicaments & Dose & $\begin{array}{l}\text { No. of practitioners with positive } \\
\text { response }\end{array}$ \\
\hline Sudarsanaghanavati -250mg & 2 tab twice daily after food & 75 \\
\hline Gudduchi tablet /SamsamanaVati -250mg & 2 tab twice after food & 110 \\
\hline $\begin{array}{l}\text { Nitya Rasayana Haridramilk or Cow } \\
\text { ghee(Emulsified fat ) - 10mlwith rice/roti }\end{array}$ & $\begin{array}{l}5 \text { gm Haridra boiledin } 250 \mathrm{ml} \text { of milk } \\
\text { and reduced to } 200 \mathrm{ml} \text {,Twice a daily }\end{array}$ & 110 \\
\hline $\begin{array}{l}\text { Chyawanprash Avaleha/ Fortified } \\
\text { Chauvanprash with Gold andsilver particle }\end{array}$ & $10 \mathrm{gm}$ once before break fast & 99 \\
\hline $\begin{array}{l}\text { Dhupana of house byResin of saal (sarjjarasa), } \\
\text { Neem leves, coconut shell and hingu. }\end{array}$ & $\begin{array}{l}\text { Morning and evening Fumigation } \\
\text { Smoke allergic patients should avoid }\end{array}$ & 110 \\
\hline Pranayama & $10-10$ min twice & 110 \\
\hline
\end{tabular}

Table: 3 Ayurvedic preventive measures for asymptomatic positive cases/A ebrile with only chills and respiratory symptoms in early stage of infection without Dyspnea and hypoxemia phase of COVID-19(n=110).

\begin{tabular}{|c|c|c|}
\hline Ayurveda medicaments & Dose & $\begin{array}{l}\text { No. of practitioners with positive } \\
\text { response }\end{array}$ \\
\hline Sudarsanaghana vat & 2 tab twice dailyafter food & 110 \\
\hline Gudduchi tablet/SamsamanaVati & 2 tab twice afterfood & 110 \\
\hline $\begin{array}{l}\text { NityaRasayana-Haridra milk or Cow ghee } \\
\text { (Emulsified fat)- } 10 \mathrm{ml} \text { with rice/roti }\end{array}$ & $\begin{array}{l}5 \mathrm{gm} \text { Haridraboilein } 250 \mathrm{ml} \text { of milkand } \\
\text { reduced to } 200 \mathrm{ml} \text {, Twice a daily }\end{array}$ & 110 \\
\hline Vyagriharitaki & $\begin{array}{l}10 \mathrm{gm} \text { twice daily with luke warm } \\
\text { water before food }\end{array}$ & 59 \\
\hline KusmandaAvaleh & $\begin{array}{l}10 \mathrm{gm} \text { twice daily with luke warm } \\
\text { water before food }\end{array}$ & 76 \\
\hline Agathiharitaki & $\begin{array}{l}\text { 10gm twice dailywith luke warm } \\
\text { water before food }\end{array}$ & 62 \\
\hline Bilvadigulika $-125 \mathrm{mg}$ & $\begin{array}{l}2 \text { tab twice dailywith luke warm } \\
\text { water before food }\end{array}$ & 73 \\
\hline Siddha Makaradwaja-125mg & $\begin{array}{l}1 \text { tab with } 2-4 \text { drop of honey in morning } \\
\text { empty stomach }\end{array}$ & 78 \\
\hline Kaphaketu rasa $-125 \mathrm{mg}$ & 2tabs with one spoon of fresh tulsi juice & 82 \\
\hline Saubhgyavati -125mg & $\begin{array}{l}\text { 2tabs with one spoon of fresh parijata leave } \\
\text { juice }\end{array}$ & 90 \\
\hline Talisadichurna & $\begin{array}{l}10 \mathrm{gm} \text { twice before with honey /luke } \\
\text { warm water }\end{array}$ & 72 \\
\hline Arogyavardhini Rasa-250 mg & 1 tablet twice daily with water after food & 67 \\
\hline
\end{tabular}

Table: 4 Ayurvedic preventive measures for uncomplicated COVID-19 infected patients having temperature $>37^{\circ} \mathrm{c}$ without dyspnea and hypoxemia $(\mathrm{n}=110)$.

\begin{tabular}{|l|l|l|}
\hline Ayurveda medicaments & Dose & $\begin{array}{l}\text { No. of practitioners with positive } \\
\text { response }\end{array}$ \\
\hline Sudarsanaghanavati & 2 tab twice daily after food & 110 \\
\hline Amrutadikasayam & $20 \mathrm{ml}$ twice with $20 \mathrm{ml}$ luke warm water before food & 110 \\
\hline Sanjeevanivati -125mg & 1 tablet before food & 80 \\
\hline SuvrnnaVasantaMalati Rasa -125mg & $\begin{array}{l}\text { 1tabs twice with one spoon of fresh } \\
\text { parijata leave juice }\end{array}$ & 110 \\
\hline SadangaPaneeya & Quantity sufficient as required when felt thirst & 92 \\
\hline Sammera Parnaga Rasa -60 mg tab & $\begin{array}{l}\text { One tablet twice with honey when kaphapredominant } \\
\text { more }\end{array}$ & 65 \\
\hline
\end{tabular}




\begin{tabular}{|l|l|l|}
\hline Vyagriharitaki & $10 \mathrm{gm}$ twice daily with luke warm water before food & 99 \\
\hline Ayush -64-250 mg cap & 2 capsule twice with water & 66 \\
\hline Agathiharitaki & $10 \mathrm{gm}$ twice daily with luke warm water before food & 92 \\
\hline Bilvadigulika -125m & 2 tab twice daily with luke warm water before food & 73 \\
\hline Purnachandra Rasa125mg & $\begin{array}{l}1 \text { tab with 2-4 drop of honey in morning empty } \\
\text { stomach }\end{array}$ & 78 \\
\hline Kaphaketu rasa -125mg & 2tabs with one spoon of fresh tulsi juice & 82 \\
\hline Saubhgyavati -125mg & 2tabs with one spoon of fresh parijata leave juice & 90 \\
\hline Talisadichurna & $10 \mathrm{gm}$ twice before with honey /lukewarm water & 72 \\
\hline Arogyavardhini Rasa -250 mg & 1 tablet -twice daily with water after food & 62 \\
\hline
\end{tabular}

\section{Homeopathic treatment: $:^{22}$}

In homeopathy, arsenic at very low concentration is considered beneficial for several diseases including viral infections. Recently, Directorate of AYUSH, New Delhi, India issued an order dater on January 30, 2020, to take prophylactic medicine to avoid coronavirus infection. The directorate suggested taking 4 pills of Arsenic Album-30 medicine once daily in empty stomach for 3 days. Arsenic Album-30 is highly diluted arsenic trioxide and work as homeopathic prophylaxis.

\section{REFERENCE}

1. WHO Director-General's opening remarks at the media briefing on COVID-19. World Health Organisation, 11 March 2020.

2. Richman DD, Whitley RJ, Hayden FG,Clinical virology, 4th ed. Washington: ASM Press; 2016.

3. Yashpal Singh Malik, ShubhankarSircar, SudiptaBhat et al: Emerging Coronavirus Disease (COVID-19), a pandemic public health emergency withanimal linkages, Current status update: 12 .

4. Naming the coronavirus disease (COVID-19) and the virus that causes it. World Health Organisation, 2020.

5. Ministry of health and family welfare government of India, 2020 .

6. PressReleseDetail Press Information Bureau Government of India: 1601095

7. Corona Updates -Ministry of Health and Family Welfare, Government of India, 2020.

8. Munster VJ, Koopmans M, van Doremalen N, van Riel D,de Wit E. Anovel Coronavirus emerging in China-Keyquestions for impact assessment. N Engl J Med2020; 382:692-4.

9. Rohit Bhatia, P. N. Sylajaet.al."Consensus Statement - Suggested Recommendations for Acute Stroke Management during the COVID19 Pandemic: Expert Group on Behalf of the Indian Stroke Association" official journal of Indian academy of neurology. 2020.

10. Latest update, Ministry of Health and Family Welfare Government of India, 25 May 2020.

11. Tarun Bhatnagar1, Manoj V. Murhekart, Manish Soneja2 et.al. "Lopinavir/ritonavir combination therapy amongst symptomatic coronavirus disease 2019 patients in India: Protocol for restricted public health emergency use" Indian Journal of Medical Research; 2020 March 13:2-3.

12. Lai CC, Liu YH, Wang CY, Wang YH, Hsueh SC, Yen MY, et al. Drug treatment options for the 2019-new coronavirus (2019-nCoV). Biosci Trends, 2020 Jan 28:01020.

13. Wang M, Cao R, Zhang L, Yang X, Liu J, Xu M, et al. Remdesivir and chloroquine effectively inhibit the recently emerged novel coronavirus (2019-nCoV) in vitro. Cell Research 2020.

14. Colson P, Rolain JM, Raoult D. Chloroquine for the 2019 novel coronavirus. Int J Antimicrob Agents, 2020 Feb 17:105923.

15. Zhou N, Pan T, Zhang J, Li Q, Zhang X, Bai C, et al. Glycopeptide antibiotics potently inhibit cathepsin $\mathrm{L}$ in the late endosome/lysosome and block the entry of Ebola virus, middle east respiratory syndrome coronavirus (MERSCoV), and severe acute respiratory syndrome coronavirus (SARS-CoV). J BiolChem 2016; 291:9218e32.

16. Colson P, Rolain JM, Lagier JC, Brouqui P, Raoult D. Chloroquine and hydroxychloroquine

17. as available weapons to fight COVID-19. Int $\mathbf{J}$ Antimicrob Agents 2020 Mar 4:105932.

18. Biot C, Daher W, Chavain N, Fandeur T, Khalife J, Dive D, et al. Design and synthesis of hydroxyferroquine derivatives with antimalarial and antiviral activities. J Med Chem 2006; 49:2845e9.

19. Liu J, Cao R, Xu M, Wang $X$, Zhang $H, H u ~ H$, et al. Hydroxychloroquine, a lesstoxic derivative of chloroquine, is effective in inhibiting SARS-CoV-2 infectionin vitro. Cell Discovery 2020; 6:16.

20. Yao X, Ye F, Zhang M, Cui C, Huang B, Niu P, et al. In vitro antiviral activity andprojection of optimized dosing design of hydroxychloroquine for the treatmentof severe acute respiratory syndrome coronavirus 2 (SARS-CoV-2). ClinicalInfect Disease, 2020 Mar 9:ciaa237.

21. Mandalam S. Seshadri and T. Jacob John. The COVID-19 Pandemic: Defining the Clinical Syndrome and Describing an Empirical Response. Christian journal for global health; 2020:41

22. Ashok KumarPanda,Amit Kumar Dixit et.al. Ayurveda Practitioners Consensus to Develop Strategies for Prevention and Treatment of Corona Virus Disease (COVID-19). Journal of Ayurveda and integrated medical science, 2020:101-103

23. ImranAli,Omar M.L.Alharbi. COVID-19: Disease, management, treatment, and social impact. science of total environment, 2020:4 